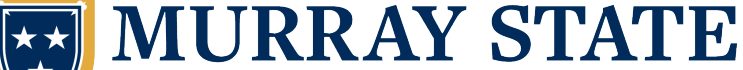 UNIVER S I T Y \\ Contemporary Rural Social Work Journal
}

Volume 7

Number 1 Promoting Environmental Justice in Rural

Article 9

Communities

$1-1-2015$

\section{Book Review: Transforming Places: Lessons from Appalachia}

Katherine Perone

Western Illinois University

Follow this and additional works at: https://digitalcommons.murraystate.edu/crsw

Part of the Social Work Commons

\section{Recommended Citation}

Perone, Katherine (2015) "Book Review: Transforming Places: Lessons from Appalachia," Contemporary Rural Social Work Journal: Vol. 7 : No. 1 , Article 9.

Available at: https://digitalcommons.murraystate.edu/crsw/vol7/iss1/9 


\section{Book Review}

\section{Transforming Places: Lessons from Appalachia}

Stephen L. Fisher \& Barbara Ellen Smith

2012

Champaign, IL: University of Illinois Press

322 pages

Softcover: \$ 27.00

Kindle: $\$ 14.00$

ISBN-13: 0252078381

ISBN-13: 978-0-252-07838-5

While other authors have focused on environmental justice, few have narrated the topic through the lens of diverse authorship. In Transforming Places, Fisher and Smith utilize the voices of many to capture the magnitude of environmental challenges in Appalachia. Beyond this, they extend these challenges nationally and globally. In their definition of Appalachia, they evoke the reader to think beyond Appalachian stereotypes. Fisher and Smith define Appalachia as a geographical region that comprises areas in the states of West Virginia, Kentucky, Virginia, Georgia, North Carolina and Tennessee. Although their definition is specific to an easily visualized central location, the definition restricts the social construct of the comprehensive Appalachia region.

This book comprises three sections in addition to the authors' introduction and concluding chapters. Excluding the authors' contributions, forty-three additional writers contributed to Transforming Places. Each chapter adds a brushstroke to the book's final canvas of environmental justice. This is evident in their selection of authors representing diverse fields of practice and scholarship. Fisher's and Smith's respect for these authors as field experts contributes to the book's validity. The term 'field expert' is used to describe contributing authors' competence based on their specializations (i.e. attorneys, teachers, human rights advocates, environmentalists, community organizers, etc.). The real life experiences these authors narrated enrich each chapter by providing readable stories of the region's social and environmental issues.

The book offers models for community organizing that encompass many disciplines. Each author contributes his or her own vision of community organizing. This vision is applied to a range of examples including community engagement, role identity, organizational models, committee work, technology and action (Brueggemann, 2014; Carlton-LaNey, Burwell, \& White, 2013; Faber \& McCarthy, 2001). For example, Chapter ten highlights the success and failures of community organizing when faith-based organizations collaborated with labor unions (Harper, 2011). This provocative illustration allows the reader to reflect on the strength and fortitude created by this kinship. Community organizing is prominent throughout the book. And based on each chapter's detailed examples, this book would benefit any macro practice classroom (Hash, Chase, \& Rishel, 2012).

Katherine Perone, Western Illinois University, Department of Health Sciences and Social Work, Email: ke-perone@wiu.edu

Copyright @ 2015 Contemporary Rural Social Work, Vol. 7 No. 1-Special Issue (Spring 2015). 
Throughout the book, the use of technology to educate and advocate changes in Appalachia, including environmental changes, is illustrated. Chapter fifteen specifically highlights the use of technology to promote the organization called Mountain Justice. The authors provide information on the organization's historical perspective as well as detailed writing on the organization's use of technology to promote environmental justice. Technological tools such as e-mail distribution lists, social media, and its own website allow Mountain Justice to create a bridge spanning rural communities locally, regionally, nationally and universally. The chapter discusses using e-mail distribution lists to communicate with members about environmental issues. The organization has used Facebook to share ideas and post pictures, newsworthy items and maintain blogs. The authors of this chapter challenged the reader to explore the Mountain Justice website to learn more about the organization.

A theme established within the book is the use of creative arts to educate and illustrate social and environmental change in the region. Chapter one tells a story which includes an illustrated example of the Oak Ridge Environmental Peace Alliance's (OREPA) use of creative arts to articulate atomic environmental waste. The book provides additional detailed examples in the use of art, music and theatre to augment the importance of community organizing for social and environmental justice.

Fisher and Smith wrote their concluding chapter which outlines the book's theoretical base. They define "place" within the context of transformations and theories of empowerment, social construction, and politics. Their critical comments regarding capitalism may offend some readers, but their final three sentences surmise their theoretical perspective:

Place is the grounds of this struggle over how we shall live in relation to one another and to the earth. Our capacity and willingness to imagine, hope, share, risk, and cooperate are critical elements in making possible visionary alternatives. In transforming places, we turn such "alternatives" into present reality and thereby open up the future for us all (Fisher \& Smith, 2012, p. 288).

This reviewer believes that Fisher and Smith embedded two subliminal questions throughout the book. The first queries the relationship between social capital, human capital and environmental capital; and the second asks at what cost will this relationship impact society. Each author in Transforming Places brings examples of the challenges and successes Appalachian advocates encountered in their journeys to rural justice. These examples not only illustrate the importance of each area as individual assets, but their regional value and strength when interconnected.

While critics may argue that the authors did not emphasize environmental justice, each chapter contributes a piece to our understanding of the concept. From the first chapter's discussion of environmental changes due to atomic testing in the 1940's to the final chapter's presentation of global changes encountered in Colombia, the environmental justice emphasis cannot be ignored. Readers not only from Appalachia, but throughout the Unites States and globally, should read this book to hear the stories and gain an understanding of the region's environmental challenges and successes. These stories measure our awareness of environmental issues, and test our ecological competency by revealing what is or is not known about the region based on one's personal knowledge or lack of knowledge. Through education, self-reflection and 
openness to new knowledge, can we as a society seek not only environmental justice, but rural justice?

\section{References}

Brueggemann, W. G. (2014). The practice of macro social work (4th ed.). Belmont, CA: Brooks/Cole Cengage Learning.

Carlton-LaNey, I., Burwell, N. Y., \& White, C. (2012). Rural community practice: Organizing, planning and development. In M. Weil., M. Reisch., \& M. L. Ohmer (Eds.), The handbook of community practice (pp. 461-478). Thousand Oaks, CA: Sage.

Farber, D., \& McCarthy, D. (2001). The evolving structure of the environmental justice movement in the United States: New models for democratic decision-making. Social Justice Research, 14(4), 405-421.

Harper, F. (2011). Greening faith: Turning belief into action for the earth. Zygon, 46(4), 957-971. doi:10.1111/j.1467-9744.2011.01231.x

Hash, K. M., Chase, P. A., \& Rishel, C. W. (2012). The community assessment: Students discovering strengths and needs in small towns and rural areas. Contemporary Rural Social Work, 4(1), 39-49. 